\title{
ANALYSIS OF THE "SOME" MODEL (SHARE, OPTIMIZE, MANAGE, ENGAGE) INSTAGRAM ACCOUNT @tnlkep Kepulauanseribu IN THE FRAMEWORK OF DIGITAL PROMOTION OF A THOUSAND ISLANDS MARINE PARK AS AN ECO-TOURISM DESTINATION FOR THE MILLENIAL GENERATION
}

\author{
Yunita Sari* \\ Postgraduate Program, Universitas Prof. Dr. Moestopo (Beragama) \\ Mediana Handayani \\ Department of Communication Science, Universitas Prof. Dr. Moestopo (Beragama) \\ *Correspondence: yunitasari@dsn.moestopo.ac.id
}

\author{
ARTICLE INFO \\ Article History: \\ received: $28 / 08 / 2020$ \\ revised: $13 / 11 / 2020$ \\ accepted: 29/12/2020 \\ Keywords: \\ Engagement; followers; \\ Instagram; Millennials; \\ Tourists \\ DOI:
}

\begin{abstract}
The fact that millennial generation is the breadwinner of the Indonesian economy cannot be ignored by the government and tourism industry businesses. The Thousand Islands Marine National Park seeks to use Instagram social media to attract potential tourists from millennial groups. A total of $110 @$ tnlkepulauaneribu uploads were then analyzed with descriptive qualitative research methods to find out how Gina Lutrell's SOME (Sharring, Optimize, Manage, Engagement) Model was used in managing the Instagram account communication @tnlkep Kepulauan Seribu as an effort to digitally promote the Thousand Islands National Park as an Ecotourism Destination for Generations Millennial. The results of this study indicate that the manager of the @tnlkepulauanseribu account has not implemented The Circular Model of SOME to the fullest. The engagement process (is the process that is at least maximally carried out. This can be seen from the lack of adequate engagement to nurture and create new followers. There are not many communication activities that can have a binding impact on followers and prospective followers of the @tnlkepulauanseribu account.
\end{abstract}

\section{INTRODUCTION}

The presence of information technology in the form of social media has had an impact on human life. One of the effects is the method of searching and conveying information. Previously, information sources were limited to conventional media with responses that sometimes took longer, nowadays various social media platforms allow information with faster traffic. Information with fairly busy traffic includes information search and delivery in the tourism sector. According to B. Zeng and R. Gerritsen (2014) "What do we know about social media in tourism? A review, "Social media applications such as Facebook, Twitter, Whatapps, and Instagram are often used by an individual or 
an institution, organization, or company as communication and information services.

At first glance, the effort to convey information through the Instagram application seems quite simple because this application only displays images and videos of a certain duration, given space to write and comment for people who are managers and followers. However, managing a communication activity via Instagram is not as simple as Instagram's motto which is "instant capture". There is a circular set of elements that can influence the success of an individual or an institution, organization, or company in managing Instagram.

The communication manager of an institution, organization, or company is not only in charge of planning the content to be shared, but also must ensure that the target target that he has is right on Instagram. Another important task for communication managers is managing real time relationships with followers or fans of an individual or an institution, organization, or company. Furthermore, communication managers must always try to make interactions that can bind followers with the company to achieve the level of engagement that the Instagram account owner is aiming for. In short, there is a social media activity management formula or management that must be followed if the owner wants to get and wants to convey information that suits his needs. Talking about information, it must be admitted that the economy is driven by information. Included in the tourism business. People will find out which tourist destinations are attractive by collecting information from various parties that are considered relevant. Currently, people will actively surf in cyberspace to get reviews of tourist destinations. Many Instagram accounts that focus on tourism provide this information and many are also used by travelers, such as research results from Fotis, JN, Buhalis, D. and Rossides, N., 2012. Social media use and impact during the holiday travel planning process. In: Fuchs.

In short, information about a tourist area will increase the attractiveness of tourists to come there. It's just that the information provided by the tour manager is sometimes not well managed, so that interesting information that should be an advantage in the tourist destination area is missed by the public. This could be what has happened so that people abroad know Bali better than Indonesia. So popular is Bali as a tourist destination that many foreign tourists think that Bali is a separate country. Even though there are so many tourist destinations in Indonesia, one of which is the Thousand Islands.

The Thousand Islands is one of the 10 New Bali Destinations which will become an icon of Indonesian tourism. Of course, this concept will further popularize the charm of Wonderful Indonesia on the world stage. The ten destinations are Lake Toba, Belitung, Tanjung Lesung, Pulau Seribu, Borobudur Temple, Mandalika, Mount Bromo Tengger, Wakatobi, Labuan Bajo, and Morotai. In this regard, Commission B DPRD DKI Jakarta Province encourages the Tourism and Culture Office (Disparbud) to improve the quality of tourism promotion for the Thousand Islands in the budget proposed in the draft General Policy Budget and Temporary Budget Priority Ceiling (KUAPPAS) for the 2020 fiscal year. Member of Commission B DPRD DKI Nur Afni Sajim, in one of the online media articles, assessed that the Thousand Islands which currently have become one of the National Tourism Strategic Areas has not succeeded in increasing the number of foreign tourist visits. In order for the promotion of tourism to be effective, Afni suggested that Disparbud rely on information technology, such as making special applications as well as utilizing social media to promote activities in the Thousand Islands. In the draft KUA-PPAS for fiscal year 2020, DKI Jakarta Disparbud proposes a tourism promotion budget of IDR 3 billion. Then IDR 1 billion for coaching actors of the arts, and IDR 525 million for assisting tourism business actors. Head of the Thousand Islands Regency Sub-dept. Of Tourism and Culture, Cucu Ahmad Kurnia, admitted that 
promotion is still lacking. "According to our survey results, there is very little promotion. It is proven that only $32 \%$ of Jabodetabek residents know about the activities there, they know there is a Thousand Island, but do not know what is in it, how much it costs there, what can be seen and the programs, " he said.

What many people don't know is that the Thousand Islands Region is actually part of the Thousand Islands Marine National Park. In order to inform about the tourism potential of the Thousand Islands Marine National Park using Instagram social media with the @tnlkep Kepulauanseribu account as well as using Twitter with the account @tnlkep Kepulauanseribu and the website www.tnlkep Kepulauanseribu.net/. When this research was made, there were 423 materials posted on the Instagram account @tnlkep Kepulauanseribu which already has 2,422 followers and follows 1,284 other accounts.

The use of Instagram, Twitter and websites to convey informational messages, in this case the promotion of tourist destinations, is considered appropriate today. Especially if the use of social media is related to Indonesia's demographic conditions. In Indonesia, 2020 is the year the demographic bonus starts, where the millennial generation is in the age range of 20 years to 40 years. This age is the productive age which will form the backbone of the Indonesian economy. Three years before this era occurred (2017), the number of millennial generations was seen to be dominant compared to other generations. According to the 2017 Susenas, the number of millennial generations reaches around 88 million people or 33.75 percent of the total population of Indonesia. This proportion is bigger than the proportion of the previous generation, such as generation $X$ (25.74 percent) and baby boomers + veterans (11.27 percent). Likewise, the number of new $\mathrm{Z}$ generation, according to National Social-Economy Survey (2017) reached around 29.23 percent.
The fact that the millennial generation is the backbone of the Indonesian economy cannot be ignored by the government and tourism industry businesses. Therefore, how the millennial generation uses communication technology is the concern of various interested parties. Fotis in his writing "Social Media Impact on Holiday" states that millennials are the heaviest social media users, who like to share their experiences online through various forms of media such as writing, photos and videos (Fotis, Buhalis, \& Rossides, 2012). These characteristics make the involvement of young people in a community vital in engaging and promoting Indonesian tourist destinations.

This research will only examine how the visual and / or audio-visual content posted by the @tnlkep Kepulauanseribu account manager in the period January 4, 2020 to May 29, 2020. From the material posted during that time, the researcher will see how the @tnlkep Kepulauanseribu account manager tries to introduce the Marine National Park. The Thousand Islands at the same time promotes the Thousand Islands as a tourist destination.

Then how is the application of the SOME Model (Sharring, Optimize, Manage, Engagement) in the management of communication on the @tnlkep Kepulauanseribu Instagram account as an effort to promote the Thousand Islands Marine National Park as an Ecotourism Destination for Millennial Generation?

\section{METHOD}

Research with the title "Model Analysis" SOME "(Share, Optimize, Manage, Engagement) Instagram Account @tnlkep Kepulauanseribu in Digital Promotion Efforts of Kepulauan Seribu Marine Park as an Ecotourism Destination for Millennial Generation was conducted in Jakarta from December 2019 to June 2020. With the Covid-19 pandemic disaster, several research activities that were planned to be carried out face-to-face must be adjusted to 
the rules of Large-Scale Social Restrictions (PSBB).

The paradigm used by researchers is the positivism paradigm. The positivism paradigm itself is a paradigm that emerged early in the world of science. The basic belief of this flow is rooted in the realism ontology which states that reality exists in reality and operates in accordance with natural laws. Research seeks to reveal the truth of the existing reality, and how this reality actually works.

Primary data is obtained from observing the feed uploads one by one at @tnlkep Kepulauanseribu. In this study, the researcher determined several informants who could be categorized as millennial generation. This consideration is because researchers want to get authentic data from the millennial generation, who often make social media the main reference in traveling.

Data collection techniques used by researchers are interviews with predetermined sources, observation of related websites, and documentation where researchers collect documents from books, theses, journals, and articles related to public relations and also social media. Meanwhile document analysis comes from website content.

Data analysis conducted by researchers was data reduction, data presentation, and data verification. One of the most important and easy ways to test the validity of research results is by triangulating (Bungin, 2008: 256). Referring to Denzin (in Bungin, 2008: 257), the technical implementation of this legality testing step can take advantage of researchers, sources, methods, and theories. In this study, researchers will use the type of source triangulation.

\section{RESULT AND DISCUSSION}

This study uses the idea of The Circular Model of Social Communication (SOME), a model created by Regina Luttrell to make it easier for social media practitioners to plan communication on social media. Luttrell introduces a model for social media planning that is the SOME circular model for social communication which consists of sharing, optimizing, managing, and engaging. The following is an explanation of the Circular model of Some according to Regina Luttrell (Luttrell, 2015: 40):

1. Share

In this section the manager of @tnlkep Kepulauanseribu must establish communication to connect, build trust, and identify channels that allow proper interactions.

2. Optimize

In this section the managers of @tnlkep Kepulauanseribu have to think seriously about what type of content should be shared in order to have maximum impact on message, brand, and also value (optimization).

3. Manage

In this section, the account manager @tnlkep Kepulauanseribu has to be managed, monitored, and measured. Managers should ideally be able to follow the interactions that occur in real-time with followers, respond to direct followers and potential followers, send private messages, share links, monitor conversations and measure success or failure.

4. Engage

In this section, the @tnlkep Kepulauanseribu account manager must create an attachment with his followers and strive for followers and potential followers to take action (call for action). Managing an engagement strategy is difficult, but when companies realize the benefits of authentic engagement the right relationship can be built.

In order to discover how the @tnlkep Kepulauanseribu account manager applies Lutrell's The Circular Model of SOME, the researchers categorized it as follows: 
Table 1. Categorization of Communication Activity Based on The Circular Model

\begin{tabular}{lll}
\hline SHARE & 1. & Relevant profile picture yang relevan with business content account \\
& 2. & Bio caption has explained ig account content with not more than 150 character \\
OPTIMIZE & 3. & Provide link website / not \\
& 1. & Content relevance \\
MANAGE & 2. & Frequency of posting \\
& 1. & Ever given interaction to others' content / not \\
ENGAGEMENT & 2. & Reply comment \\
& 1. & There is CTA (Call for Action - like, comment, save \& share) \\
& 2. & The use of appropriate hashtag \\
\hline
\end{tabular}

Source: Luttrell, 2015

Researchers saw the application of Share by looking at the availability of profile pictures that are relevant to the business / account content, the availability of Bio captions, and the availability of website links. Researchers found that the profile picture used in @tnlkep Kepulauanseribu is relevant to the information that we want to provide. Likewise with the caption in the bio. However, only some of the content linked by the link is Podcast.

Researchers saw the implementation of Optimize by looking at the relevance of the content and the frequency of uploading. Researchers found that the content on @tnlkep Kepulauanseribu is relevant to the purpose for which the account was created. Posts are quite effective starting from the hours when people open IG frequently, and you don't see spamming posts.

Researchers saw Manage
implementation by looking at the interaction of the manager @tnlkep Kepulauanseribu to other people's content and the availability to reply to comments. Researchers found that it was rare to find such interactions. The account manager @tnlkep Kepulauanseribu rarely responds to other people's comments on their uploads.

Researchers observe Engage implementation by seeing if there is a CTA (Call for Action - like, comment, save \& share) in the upload, as well as the use of sufficient and relevant hashtags. Hashtag related \#kementrianlhk \#kep Kepulauanseribu \#AHK \#AseanHeritagePark because many people use this hashtag. Only a few of IG @tnlkep Kepulauanseribu collaborate with parties that invite the public to go to the Thousand Islands. There is no CTA because all content is not invited by other people to share, like, and comment. Comments that are not relevant to the post are rarely replied to.

Table 1. Results of Upload Analysis on @tnlkep Kepulauanseribu Account based on Visual Text and or Audio Visual Display

\begin{tabular}{|c|c|c|}
\hline No. & Element & Finding \\
\hline 1. & Relevant or not relevant content. & $\begin{array}{l}\text { More relevant content includes information provided to } \\
\text { the audience }\end{array}$ \\
\hline 2. & $\begin{array}{l}\text { Post frequency. Posting too often (impressed } \\
\text { spamming) / just the right amount. }\end{array}$ & $\begin{array}{l}\text { Posts are quite effective starting from the hours that } \\
\text { people open IG frequently, and do not see spamming posts }\end{array}$ \\
\hline 3. & $\begin{array}{l}\text { Using Overused Hashtags. Hashtag related / } \\
\text { not. }\end{array}$ & $\begin{array}{l}\text { Hashtag related to \#kementrianlhk \#kep } \\
\text { Kepulauanseribu \#AHK \#AseanHeritagePark because } \\
\text { many people use this hashtag. }\end{array}$ \\
\hline 4. & $\begin{array}{l}\text { Ever give interaction to other people's content } \\
\text { / not. }\end{array}$ & $\begin{array}{l}\text { Only a few of IG @tnkkep Kepulauanseribu collaborate } \\
\text { with parties that invite the public to go to the Thousand } \\
\text { Islands. }\end{array}$ \\
\hline 5. & $\begin{array}{l}\text { There is a CTA (Call for Action - like, comment, } \\
\text { save \& share) in content / not }\end{array}$ & $\begin{array}{l}\text { Not available because all content is not invited by other } \\
\text { people to share, like, and comment. }\end{array}$ \\
\hline 6. & $\begin{array}{l}\text { Reply to comments / no response to comments } \\
\text { on posts }\end{array}$ & $\begin{array}{l}\text { Comments that are not relevant to the post are rarely } \\
\text { replied to. }\end{array}$ \\
\hline 7. & $\begin{array}{l}\text { Profile picture relevant to the business / } \\
\text { account content }\end{array}$ & Relevant with the information you want to provide. \\
\hline 8. & $\begin{array}{l}\text { The bio caption has explained the contents of } \\
\text { the IG account with no more than } 150 \\
\text { characters }\end{array}$ & $\begin{array}{l}\text { Clear enough to explain the content of the content } \\
\text { regarding the content, when, where, what is it. }\end{array}$ \\
\hline
\end{tabular}




\section{Discussion}

If we look closely at the data findings, there are several things that seem to be weaknesses of the @tnlkep Kepulauanseribu account manager. One of these weaknesses has to do with content issues. The content uploaded by @tnlkep Kepulauanseribu often has the feel of an internal report from an organization with a bureaucratic flavor. The coverage uploaded to the account is not interesting coverage for the millennial generation who are specifically looking for information about ecotourism destinations. In short, the visualization of content uploaded on $@$ tnlkep Kepulauanseribu has not been too successful to be called interesting, as discussed in previous studies, Korže, Saša Zupan (2019). From Industry 4.0 to Tourism 4.0, Luttrell, Regina. (2015). How To Engage, Share, and Connect, Pereira, A.C. \& Romero, F. (2017). A review of the meanings and implications of the Industry 4.0, and Smith, Richard. (2015). Smart Tourism: Linking technology with the touristic resources of city destination.

According to Fardiyandi, an entrepreneur who specializes in digital marketing strategy, visual content will help the brain process information better. Because humans will remember $80 \%$ of things by looking at pictures and $20 \%$ by reading. Although reading interest in Indonesia is classified as low, the explanation of information in written form will provide a more complete understanding than visual content. In content marketing, these two things must go hand in hand. This human tendency is what causes Microblogging content to become a trend on Instagram today. According to Fardiyandi, Instagram users want to get education, but not with burdensome media. Life is complicated enough, so they avoid content that actually makes "life more complicated."

Keep the content simple but still attractive. This means that the @tnlkep
Kepulauanseribu account manager must have copy writing skills. So both visuals and writing must be present, only the portion will adjust depending on who is the target audience of @tnlkep Kepulauanseribu and the platform. It must be remembered that the best content is content that can provide value to others, is packaged in a simple language style, plus an attractive visual appearance.

One more thing that can make the content of @tnlkep Kepulauanseribu enjoyable is if the content is useful for the audience. And this in turn will make followers and potential followers more engaged, at least it will give likes. Knowing the power of content helps the managers of @tnlkep Kepulauanseribu to be more focused on creating it. Know what content to create by knowing who the @tnlkep Kepulauanseribu audience is. When you know who and what you want, your audience will know what content they want. When the @ tnlkep Kepulauanseribu account manager knows what content followers and potential followers want, the follower and potential follower will help @tnlkep Kepulauanseribu to continue to develop accounts and provide ideas for @tnlkep Kepulauanseribu content.

The manager of @tnlkep Kepulauanseribu should review content performance at least once a week to improve further content creation. Document all impressions of the @tnlkep Kepulauanseribu content, and record what day the manager uploaded, what time and what themed content. This will help the account manager find out which content characters the audience likes.

So that the manager can provide a good caption, he needs to understand in depth who the audience is being targeted by the account. It's better to be more focused in making caption managers focus on a niche where the character can really be explored what the market really needs. In this case the 
manager should focus more on potential tourist groups from the millennial generation group. Account managers must explore the style of the millennial generation, the problems faced by them, and how the millennial generation looks for solutions. So in writing captions in content, managers should not focus too much on information about who and what the Thousand Islands National Marine Park is doing, but also provides information needed by potential tourists.

Regarding uploads, things that need to be considered are that in the first 30 minutes after an upload is posted, make sure that at least there is an interaction that occurs. Comments are very influential. Managers can initiate interactions with posts of parties who have an interest in what the Seribu Islands Marine National Park is doing. According to Fardiyandi, a post was only seen by $10 \%$ of the account's total followers. To increase this number, try to interact with what other people upload.

Managers must also pay attention to hashtags. In the @tnlkep Kepulauanseribu account, there is already a hahstag group that allows managers to use hashtags interchangeably so they don't experience spam. Hashtag is like a vehicle. There are those who bring the content of the Thousand Islands National Marine Park faster and more to more people, but there are also those who are not maximized, slow and unfocused. That's why hashtag research is important. Take advantage of the opportunity to find hashtag references that match the content created.

There are three types of hashtags, namely hashtags with high traffic, medium traffic, and low traffic. Each account has a maximum number of hashtags in our posts of 30 hashtags. Take advantage of these 30 hashtags to cover the 3 types of hashtags mentioned earlier. High traffic means having millions of users. Medium traffic has up to hundreds of thousands of traffic. Low traffic is more of a trend that you want to create.

1. The account manager @tnlkep Kepulauanseribu needs to add more
CTAs (call to action) in their content. Ask a simple question or invitation that invites response. For example, by making a statement like this: "If you like this content, let's help me build engagement. To do this, please like, comment, save \& share this content with your friends. Thank you." Researchers also suggest that managers:

2. Spend more time consistently posting to Instagram

3. Use IG features such as notification and facebook page manager

4. Use a tool that can pay attention to comments entered on IG @tnlkep Kepulauanseribu posts.

5. Find out when is the most active time that the targeted audience @tnlkep Kepulauanseribu has

6. Experiment with more video content on the @tnlkep Kepulauanseribu feed to see how video affects engagement rates.

7. Spend more time posting consistently to IG stories.

8. Use IGTV in posts @tnlkep Kepulauanseribu to increase engagement.

\section{CONCLUSION}

The Thousand Islands National Marine Park which utilizes Instagram social media in an effort to increase the level of knowledge of millennial generation tourists about the Thousand Islands National Marine Park has implemented Gina Lutrell's The Circular Model of SOME. This application cannot be said to have been done optimally. Some of the things that underlie the assessment of the less than optimal application of The Circular Model of SOME are as follows:

1. Share Process in Communication Planning via Instagram @tnlkep Kepulauanseribu: The target audience is equated with the positioning of the Thousand Islands National Marine Park as an institution under the authority of the Ministry of Environment. This results in unclear targets. On the one 
hand, this account wants to appear with youthful content in accordance with the millennial character as potential tourists to be targeted, but on the other hand the content uploaded on this account is very bureaucratic and not oriented to audience needs. As an institution that manages the environment, of course the Thousand Islands National Marine Park must build public trust by making several efforts, namely by posting certain content that can foster public confidence in the appropriateness of the Marine National Park to be a steward of the environment as well as an ecotourism destination, including a review of guests, repost photos posted by guests, and also post photos of the institution's activities in ensuring the environment in the marine park is maintained.

2. Optimize Process in Communication Planning via Instagram @tnlkep Kepulauanseribu: At the communication planning stage, the Thousand Islands National Marine Park uses a timeline schedule as a guide for its Instagram planning. Listen and Learn, which should be done in every planning, only done when there is content that gets good feedback. The Thousand Islands National Marine Park also does not practice "take part in authentic conversations" in its communication planning. In optimizing the message, the Marine National Park optimizes the content to be distributed by adjusting the photography style and captions that are adjusted to the standardization and positioning of the Seribu Islands Marine National Park. The time in posting follows the worker's habit, namely the morning before work, the afternoon during rest hours, and the evening after the work hour ends. The best time to upload existing insights is not used even though it is very helpful for the process of optimizing the distribution of messages.
3. Manage Process in Communication Planning via Instagram @tnlkep Kepulauanseribu: At the media monitoring stage, the monitoring media carried out did not include followers, hashtags, top posts, gender, age, and top locations. The importance of using website analytics to conduct media monitoring does not seem to be owned by the account manager. The evaluation process also does not involve followers, engagement, uploaded content, incoming feedback, and also the best time to post. The evaluations that have been obtained are not taken into consideration for further planning and are often not used as improvements. There is no more engagement aspect in the evaluation. Management of feedback is done manually via the Instagram application, not using the social media dashboard. Management of feedback is not done quickly and it is often ignored and not answered, from the results of observation there are often unanswered comments. The Thousand Islands National Marine Park also rarely does 'real time interactions'.

4. Engage Process in Communication Planning via Instagram @tnlkep Kepulauanseribu: Based on the results of the document study obtained, in the process of engaging the Thousand Islands National Marine Park has not made an approach to stakeholders, namely to brand influencers and the public. The Thousand Islands National Marine Park does not have brand influencers, even though to attract followers from millennials, the use of brand influencers is common. If one day the Thousand Islands National Marine Park uses an influencer brand, you can use a holiday or ecotourism experience in the national park. Through the holiday or ecotourism experience, the public figures will share their experiences with their followers. The shared content can also be tailored to the needs of the Thousand Islands 
National Marine Park. However, brand influence activities are sometimes not maximal because they are not monitored in their implementation so that engagement is maintained. The Thousand Islands National Marine Park should strive to engage with audiences or followers by uploading attractive and entertaining content such as interactive quizzes, photo or video contests, events taking place around the marine park or even those currently taking place in Bandung, even international, national holiday, the history of the Thousand Islands National Marine Park or the Thousand Islands itself, to the life quote that is suitable for everyday life.

\section{REFERENCE}

B. Zeng and R. Gerritsen (2014) "What do we know about social media in tourism? A review," Tour. Manag. Perspect., vol. 10, pp. 27-36

Fotis, J. N., Buhalis, D. and Rossides, N., 2012. Social media use and impact during the holiday travel planning process. In: Fuchs, M., Ricci, F. and Cantoni, L., eds. Information and Communication Technologies in Tourism 2012. Vienna, Austria: Springer-Verlag, 13-24.

Hajati, Rizky Pratama Susie Perbawati dan Hanny Hafiar (2018). Manajemen Aktivitas Media Sosial Akun Instagram @indonesiabaik.id. Jurnal MetaCommunication; Journal of Communication Studies Vol. 3 No. 2 September 2018.

Hidayanti, Rafiqa dan Martunis Yahya. Peran Media Baru dalam Membentuk Komunitas Virtual

(Studi pada Mahasiswa yang Bergabung dalam Komunitas Acehvidgram di Instagram). JIM FISIP UNSYIAH VOL 2, NO 2 (2017).

Ikbal, Muhammad dan Mochammad Abdul Ghofur (2019). Efektivitas Unggahan Foto di Akun

Instagram @indotravellers.co terhadap Minat Berlibur Komunitas Backpacker
Malang." Jurnal Ilmu Sosial dan Ilmu Politik Vol. 8, No. 1 (2019).

IDN Research Institute bekerjasama dengan Alvara Research Center di 12 kota besar di Indonesia.

Indonesia Millenial Report 2019

Korže, Saša Zupan (2019). From Industry 4.0 to Tourism 4.0. Innovative Issues and Approaches in

Social Sciences, Vol. 12, No. 3

Luttrell, Regina. (2015). Social Media: How to Engage, Share, and Connect. London: Rowman and Littlefield.

Pereira, A.C. \& Romero, F. (2017). A review of the meanings and implications of the Industry 4.0 Concept. Procedia Manufacturing 13, pp. 1206-1214.

Smith, Richard. (2015). Smart Tourism: Linking technology with the touristic resources of city destination. NHTV University of Applied Sciences, Breda

Survei Sosial Ekonomi Nasional (Susenas), BPS). 2017

http://dprd-

dkijakartaprov.go.id/disparbud-

didorong-tingkatkan-kualitas-

promosi-pulau-seribu-di-2020/

World Economic Forum (WEF). (2019) Laporan The Travel \& Tourism Competitiveness

Report. 